\section{Sodium Helps Overcome Potassium Deficiency Effects on Water Relations of Cauliflower}

\author{
C.P. Sharma and Sandhya Singh \\ Department of Botany, Lucknow University, Lucknow-226007, India
}

Additional index words. Brassica oleracea, relative water content, leaf water potential, transpiration, diffusive resistance, proline

Abstract. When grown in refined sand with one-twentieth normal $\mathrm{K}$ supply, cauliflower (Brassica oleracea L. var. botrytis L. CV. Pusi) had lower dry matter and tissue concentration of $\mathrm{K}$ than the controls and developed visible symptoms characteristic of $\mathrm{K}$ deficiency. In K-deficient plants, the specific leaf weight, diffusive resistance, and proline concentration in leaves were significantly higher and relative water content (RWC), leaf water otential $(\psi)$, stomatal aperture, stomatal density, and transpiration rate were significantly lower than in control plants. When K-deficient plants were supplied additional $\mathrm{Na}$ to the extent $\mathrm{K}$ was deficient, $\mathrm{Na}$ concentration in the plants increased and the plants recovered from the $\mathrm{K}$ deficiency effect on free proline concentration, RWC, leaf water potential, stomatal aperture, stomatal density, specific leaf weight, diffusive resistance, and transpiration.
In an earlier study we have shown that cauliflower requires $4 \mathrm{~mm} \mathrm{~K}$ supply for normal growth (Singh and Sharma, 1988a). Plants grown at suboptimal $\mathrm{K}$ showed retarded growth and increased water stress (Sharma et al., 1985; Singh and Sharma, 19886). Beneficial effects of $\mathrm{Na}$ and the subolism in several species have been documented (Flower and Läuchli, 1983). Our study was undertaken to determine whether the disturbance in water relations caused by low supply of K can be overcome by supplying Na.

Cauliflower was grown in refined sand $(0.2 \mathrm{~mm}) \mathrm{K}$, supplied as sulfate, in white plastic pots of 8-liter capacity. Plants receiving low $\mathrm{K}$ were grown in two lots, one was supplied $3.8 \mathrm{~mm} \mathrm{Na}$ as sodium sulfate, the other lot was maintained without any additional Na. Nitrogen was supplied as a combination of $4 \mathrm{~mm}$ nitrate and $2 \mathrm{~mm}$ ammonium. The composition of the basal nutrient solution was, in mM: $4 \mathrm{Ca}\left(\mathrm{NO}_{3}\right)_{2}$; $2 \mathrm{MgSO}_{4}, 1.33\left(\mathrm{NH}_{4}\right)_{2} \mathrm{HPO}_{4} ; 0.1 \mathrm{NaCl} ; 0.1$ Fe-EDTA: in $\mu \mathrm{M}$ : $10 \mathrm{MnSO}_{4} ; 1 \mathrm{CuSO}_{4} ; 1$ $\mathrm{ZnSO}_{4} ; 33 \mathrm{H}_{3} \mathrm{BO}_{3} ; 0.2 \mathrm{Na}_{2} \mathrm{MoO}_{4} ; 0.1 \mathrm{CoSO}_{4}$ and $0.1 \mathrm{NiSO}_{4}$. Plants were maintained under glasshouse conditions for 123 days. Each

Received for publication 29 Aug. 1988. The cost of publishing this paper was defrayed in part by the payment of page charges. Under postal regulations, this paper therefore must be hereby marked advertisement solely to indicate this fact. stitution of $\mathrm{Na}$ for $\mathrm{K}$ in growth and metab(Hewitt, 1966) with normal (4 mm) and low pot was supplied $500 \mathrm{ml}$ of nutrient solution daily around 10 AM. The effect of supplying $\mathrm{Na}$ to K-deficient plants was examined in comparable leaves (4 to 5 from the top) of 57-day-old plants.

Potassium and $\mathrm{Na}$ were determined by flame photometry after digesting the ovendried material in a mixture of 10 nitric acid :1 perchloric acid (Piper, 1942). Proline was measured calorimetrically as ninhydrin complex in toluene by the method of Bates et al. (1973). Leaf water potential and RWC were measured about $10 \mathrm{Am}$, when the sand in the pots was saturated with nutrient solution. Leaf water potential was determined by Shardakov technique (Kozlowski, 1964). Leaf disks were immersed in small volumes of test solutions of various concentrations of sucrose lightly colored with methylene blue. After exposure, drops of the colored solutions were transferred with a micropipette to colorless solutions of the same initial concentration of sucrose and the movement of the colored drop in the solution was observed. The test solution in which the colored drop became stationary corresponded to the water potential of the leaf disks. Relative water content (RWC) was measured according to Barrs and Weatherly (1962). The 30 leaf disks $7.5 \mathrm{~mm}$ in diameter used for RWC measurements were also used for determining specific leaf weight. Dry weight was determined after drying the tissue disks at $105 \mathrm{C}$ for $24 \mathrm{HR}$. Diffusive resistance and rate of transpiration were measured in intact leaves using a LI-COR model LI-1600 (LI-COR, Lincoln, Neb.) steady-state porometer about $10 \mathrm{AM}$ under glasshouse conditions [24C, $57 \% \mathrm{RH}$, and light intensity (PAR) ranging from 400 to $\left.700 \mu \mathrm{mol} \cdot \mathrm{s}^{-1} \cdot \mathrm{m}^{-2}\right]$. Stomatal density and stomatal width were measured microscopically using microrelief impression of leaf surfaces (Sharma et al., 1982). Transpiration and diffusive resistance were measured on nine replicates. All other measurements were made on three replicates. The results have been tested for significance using Duncan's multiple range test.

Low supply of K retarded the growth of cauliflower. Leaves of the low-K plants developed mild chlorosis and their lamina appeared undulated. The severity of the visible symptoms was lessened by additional supply of $\mathrm{Na}$. Compared to plants grown at $4 \mathrm{~mm}$ $\mathrm{K}$, plants grown at $0.2 \mathrm{~mm} \mathrm{~K}$ contained less total dry matter (Table 1). Additional $\mathrm{Na}$ partially (not significantly) ameliorated the K-deficiency effect on dry matter. Leaf tissue concentrations of $\mathrm{K}$ in low-K plants were significantly less than in normal-K plants. Additional supply of $\mathrm{Na}$ to low-K plants did not make any significant change in the leaf tissue concentration of K. Deficiency of K caused a significant increase in Na concentration (Table 1). The effect became still more marked when the K-deficient plants were supplied $\mathrm{Na}$ to the extent $\mathrm{K}$ was omitted from the nutrient medium.

Potassium affected stomatal opening (Table 1). A large proportion of the stomata in leaves of K-deficient plants remained closed
Table 1. Effect of supplying $\mathrm{Na}$ to low-K plants on dry matter, tissue concentration of $\mathrm{K}$ and $\mathrm{Na}$, stomatal aperture and stomatal density in leaves of cauliflower. ${ }^{z}$

\begin{tabular}{ccccccc}
\hline \hline $\begin{array}{c}\mathrm{K} \text { and Na } \\
\text { supply } \\
(\mathrm{mM})\end{array}$ & $\begin{array}{c}\text { Dry } \\
\text { matter } \\
(\mathrm{g} / \mathrm{plant})\end{array}$ & $\begin{array}{c}\mathrm{K} \\
\left(\mathrm{mmol} \cdot \mathrm{g}^{-1}\right. \\
\mathrm{dry} \mathrm{wt})\end{array}$ & $\begin{array}{c}\mathrm{Na} \\
\left(\mathrm{mmol} \cdot \mathrm{g}^{-1}\right. \\
\mathrm{dry} \mathrm{wt})\end{array}$ & $\begin{array}{c}\text { Stomatal } \\
\text { aperture } \\
(\mu \mathrm{m})\end{array}$ & $\begin{array}{c}\text { Sbaxial } \\
\text { surface }\end{array}$ & $\begin{array}{c}\text { Adaxial } \\
\text { surface }\end{array}$ \\
\hline $\begin{array}{c}4.00 \mathrm{~K}^{+} \\
0.20 \mathrm{~K}^{+}\end{array}$ & $0.658 \mathrm{a}$ & $1.06 \mathrm{a}$ & $0.17 \mathrm{c}$ & $5.56 \mathrm{a}$ & $4.27 \mathrm{a}$ & $2.07 \mathrm{a}$ \\
$0.20 \mathrm{~K}^{+}+$ & $0.524 \mathrm{~b}$ & $0.16 \mathrm{~b}$ & $0.56 \mathrm{~b}$ & $2.16 \mathrm{c}$ & $2.55 \mathrm{c}$ & $1.45 \mathrm{~b}$ \\
$3.80 \mathrm{Na}^{+}$ & $0.581 \mathrm{~b}$ & $0.17 \mathrm{~b}$ & $1.25 \mathrm{a}$ & $4.23 \mathrm{~b}$ & $3.00 \mathrm{~b}$ & $2.07 \mathrm{a}$ \\
\hline
\end{tabular}

${ }^{2}$ Mean separation within columns by Duncan's multiple range test, $P=0.05$. Data are means of three replicates. 
Table 2. Effect of supplying $\mathrm{Na}$ to low-K plants on transpiration, diffusive resistance, specific leaf weight, RWC, and free proline in leaves of cauliflower. ${ }^{\mathrm{z}}$

\begin{tabular}{|c|c|c|c|c|c|c|}
\hline $\begin{array}{c}\mathrm{K} \text { and } \mathrm{Na} \\
\text { supply }\end{array}$ & $\begin{array}{l}\text { Transpiration } \\
\left(\mathrm{g} \cdot \mathrm{s}^{-1} \cdot \mathrm{cm}^{-2}\right)\end{array}$ & $\begin{array}{l}\text { Diffusivey } \\
\text { resistance } \\
\left(\mathrm{s}^{\cdot} \mathrm{cm}^{-1}\right)\end{array}$ & $\begin{array}{l}\text { Specific } \\
\text { leaf } \mathrm{wt}^{\star} \\
\left(\mathrm{g} \cdot \mathrm{cm}^{-2}\right)\end{array}$ & $\begin{array}{c}\mathrm{RWC}^{\mathrm{x}} \\
(\%)\end{array}$ & $\begin{array}{c}\psi^{\mathbf{x}} \\
(\mathrm{kPa})\end{array}$ & $\begin{array}{c}\text { Proline } \\
(\mu \mathrm{mol} / 100 \mathrm{~g} \\
\text { fresh wt) }\end{array}$ \\
\hline $4.00 \mathrm{~K}^{+}$ & $530 \mathrm{~b}$ & $2.72 \mathrm{~b}$ & $0.074 \mathrm{c}$ & $9171 \mathrm{a}$ & $-267 b$ & $92 \mathrm{~b}$ \\
\hline 20 & & $4.02 \mathrm{a}$ & 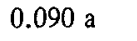 & $00.41 \mathrm{D}$ & a & 163 a \\
\hline $20 \mathrm{~K}^{+}+$ & & & & & & \\
\hline $3.80 \mathrm{Na}^{+}$ & $7.55 \mathrm{a}$ & $2.14 \mathrm{~b}$ & $0.081 \mathrm{~b}$ & $92.14 \mathrm{a}$ & $-107 \mathrm{c}$ & $153 \mathrm{a}$ \\
\hline
\end{tabular}

${ }^{2}$ Mean separation within columns by Duncan's multiple range test, $P=0.05$.

YData are means of nine replicates.

×Data are means of three replicates.

at all times of the day. In the few stomata that were open, the width of aperture was less than half that in control plants. Supplying $\mathrm{Na}$ to low-K plants caused a significant increase in stomatal opening, but stomatal aperture of plants supplied additional $\mathrm{Na}$ still remained significantly less than in normal plants.

Potassium deficiency caused a significant decrease in stomatal density on both leaf surfaces (Table 1). Supplying Na to K-deficient plants ameliorated this effect.. There was no significant difference in the stomatal density on the adaxial surface of leaves of plants supplied additional $\mathrm{Na}$ or the corresponding surface of normal plants, but stomatal density on the abaxial surface of leaves of plants supplied additional Na still remained significantly lower than the corresponding surface of normal plants.

Deficiency of K significantly decreased the rate of transpiration (Table 2). When K-deficient plants were supplied $\mathrm{Na}$ to the extent $\mathrm{K}$ was deficient, the transpiration rate showed an increase that was not only significantly higher than of leaves of K-deficient plants but also higher than leaves of normal plants. The leaves of low-K plants had significantly higher diffusive resistance and specific leaf weight and lower RWC and $\psi$ than in control plants (Table 2). Potassium-deficient leaves also accumulated significantly more proline than leaves of K-sufficient plants and the supply of Na did not make any significant difference in its accumulation (Table 2). Supplying $\mathrm{Na}$ to K-deficient plants reduced all these effects. There was no significant difference in RWC and diffusive resistance between low-K plants supplied $\mathrm{Na}$ and normal $\mathrm{K}$ plants.

The $\psi$ of the plants supplemented with $\mathrm{Na}$ became significantly less negative than control plants, but specific leaf weight of low$\mathrm{K}$ plants supplied $\mathrm{Na}$ still remained significantly higher than specific leaf weight of normal plants.

Observed changes in stomatal aperature, RWC, transpiration, diffusive resistance, and proline accumulation in cauliflower plants subjected to $\mathrm{K}$ deficiency are in accord with our earlier observations (Sharma et al., 1985; Singh and Sharma, 1988b). High specific leaf weight, low RWC, low $\psi$, and increased accumulation of proline in leaves of cauliflower plants supplied low $\mathrm{K}$ indicate a state of water stress that seems to result from poor absorption or restricted transport of water, thus leading to increased stomatal resistance and decreased transpiration. Changes in RWC, $\psi$, transpiration, and stomatal resistance by supplying $\mathrm{Na}$ in place of $\mathrm{K}$ suggest a beneficial effect of $\mathrm{Na}$ in overcoming $\mathrm{K}$ deficiency on water balance of cauliflower. In fact, the Na effect on transpiration seems to be more marked than the K effect. Beneficial response to $\mathrm{Na}$ is known to occur in salttolerant species, such as sugarbeet, where $\mathrm{Na}$ replaces $\mathrm{K}$ and contributes to the solute potential and consequent generation of turgor (Marschner and Possingham, 1975), thus affecting growth and water balance of the plants (Durrant et al., 1978; Lawlor and Mil- ford, 1973; Milford et al., 1977). In any case, $\mathrm{Na}$ effectively compensates for $\mathrm{K}$ deficiency.

\section{Literature Cited}

Barrs, H.D. and P.E. Weatherly. 1962. A re-examination of the relative turgidity technique for estimating water deficits in leaves. Austral. J. Biol. Sci. 15:413-428.

Bates, L.S., R.P. Waldren, and I.D. Teare. 1973. Rapid determination of the proline for stress studies. Plant \& Soil 39:205-207.

Durrant, M.J., A.P. Draycott, and G.F.J. Milford, 1978. Effect of sodium fertilizer on water status and yield of sugarbeet, Ann. Applied Biol. 88:321-328

Flower, T.J. and A. Läuchli. 1983. Sodium versus potassium: substitution and compartmentalization, p. 651-681. In: A. Läuchli and R.L. Bieleski (eds.). Encyclopedia of plant physiology, New Ser. vol. 15B. Inorganic plant nutrition. Springer, Berlin.

Hewitt, E.J. 1966. Sand and water culture methods used in the study of plant nutrition. 2nd ed. Commonw. Agr. Bur., England.

Kozlowski, T.T. 1964. Water metabolism in plants, Biol. Monogr. Harper, New York.

Lawlor, D.W. and G.F.J. Milford. 1973. The effect of sodium on growth of water stressed sugarbeet. Ann. Bot.. (London) (N. S.) 37:597604.

Marschner, H. and J.V. Possingham. 1975. Effect of $\mathrm{K}^{+}$and $\mathrm{Na}^{+}$on growth of leaf discs of sugarbect and spinach. Z. Pflanzenphysiol. 75:616.

Milford, G.F.J., W.F. Cormack, and M.J. Durrant. 1977. Effects of sodium chloride on water status and growth of sugarbeet. J. Expt. Bot. 28:1380-1388.

Piper, C.S. 1942. Soil and plant analysis, The University, Adelaide, Australia.

Sharma, C.P., P.N. Sharma, S.S. Bisht, and B.D. Nautiyal. 1982. Zinc deficiency induced changes in cabbage, p. 601-606. In: A. Scaife (ed.). Plant nutrition. vol. 2. Commonw. Agr. Bur., England.

Sharma, C.P., P.N. Sharma, and S. Singh. 1985. Potassium and iron inter-relationship in water relations of cauliflower. Ind. J. Plant Nutr. 4:167-175.

Singh, S. and C.P. Sharma. 1988a. Potassium nutrition of cauliflower. J. Hort. Sci. 63:629-633.

Singh, S. and C.P. Sharma. 1988b. Effect of potassium on leaf diffusive resistance and transpiration. Curr. Sci. 57:393-394. 